\title{
Perancangan Sistem Informasi Klinik Hewan Berbasis Android
}

\author{
Saghifa Fitriana1, Yustina Meisella Kristania $^{2}$ \\ ${ }^{1,2}$ SistemInformasi, Universitas Nusa Mandiri \\ Indonesia \\ *E-mail : saghifa.sff@nusamandiri.ac.id,yustina.yms@nusamandiri.ac.id
}

\begin{abstract}
Pets are animals that are cared for and cared for by humans. Nowadays many people are interested in owning a pet. Of course, the existence of a veterinary clinic in an area will greatly assist animal lovers in caring for their favorite animals. In the Digital Era as it is today, the use of sophisticated technology is certainly an option for business actors, in this particular case, veterinary clinics. Especially during a pandemic like this, waiting in line will certainly be avoided. However, at this time, several veterinary clinics in Purwokerto have not utilized the sophistication of existing technology so that the data management process is still manual for each running process. Therefore, an information system application is needed to help the process flow at the clinic run computerized. In this application there will be three users, namely patients, officers and doctors. To design this application using the waterfall method and for implementation using Android so that it can be used mobile via smartphones and is more flexible in its use. With the android-based application, it is hoped that it can help the transaction process for animal owners and clinics.
\end{abstract}

\section{Keywoard : System planning; Information Systems; Veterinary Clinic; Android}

\begin{abstract}
Abstrak
Hewan peliharaan merupakan hewan yang dipelihara dan dirawat oleh manusia. Saat ini banyak orang yang menaruh minat untuk memiliki hewan peliharaan. Tentunya keberadaan klinik hewan di suatu daerah akan sangat membantu para pecinta hewan dalam memelihara hewan kesayangan mereka. Di Era Digital seperti sekarang ini pemanfaatan teknologi yang canggih tentu menjadi pilihan bagi para pelaku usaha, dalam hal ini khususnya yaitu klinik hewan. Apalagi di masa pandemic seperti ini untuk menunggu antrian tentu akan dihindari. Namun pada saat ini, beberapa klinik hewan di Purwokerto belum memanfaatkan kecanggihan teknologi yang ada sehingga proses pengelolaan data masih secara manual untuk setiap proses yang berjalan. Maka dari itu dibutuhkan sebuah Aplikasi Sistem informasi untuk membantu alur proses pada klinik tersebut berjalan secara terkomputerisasi. Dalam aplikasi ini akan terdapat tiga user yaitu pasien, petugas dan dokter. Untuk merancang aplikasi ini menggunakan metode waterfall dan untuk implementasi menggunakan android supaya dapat digunakan secara mobile melalui smartphone dan lebih fleksibel dalam penggunaannya. Dengan adanya aplikasi berbasis android diharapakan dapat membantu proses transaksi bagi pemilik hewan maupun klinik.
\end{abstract}

Kata Kunci: Perancangan Sistem; Sistem Informasi; Klinik Hewan; Android 


\section{Pendahuluan}

Teknologi informasi dapat didefinisikan sebagai perpaduan antara teknologi komputer dan telekomunikasi dengan teknologi lainnya seperti perangkat keras, perangkat lunak, database, teknologi jaringan, dan peralatan telekomunikasi lainnya. Selanjutnya, teknologi informasi dipakai dalam sistem informasi organisasi untuk menyediakan informasi bagi para pemakai dalam rangka pengambilan keputusan dan untuk mencapai tujuan yang spesifik. Melalui sistem informasi yang berbasis teknologi, informasi menjadi mudah, akurat, efektif, dan efisien.

Hewan peliharaan merupakan hewan yang dipelihara dan dirawat oleh manusia. Saat ini banyak orang yang menaruh minat untuk memiliki hewan peliharaan. Dengan meningkatnya rasa cinta terhadap hewan kesayangan, menyebabkan timbulnya suatu kebutuhan yang besar akan suatu tempat yang benar-benar dapat menampung dan menyediakan berbagai alat, bahan dan jasa yang berkaitan dengan perawatan dan pemeliharaan hewan-hewan kesayangan (Rebecca, 2012). Dalam pemeliharaan hewan sendiri, terdapat beberapa hal yang harus diperhatikan salah satunya adalah kesehatan hewan tersebut. Namun ternyata masih banyak terjadi kasus menelantarkan hewan peliharaan. Kurangnya edukasi tentang hewan peliharaan juga berdampak pada hal negatif lainnya, antara lain bertambahnya kasus perdagangan satwa yang dilindungi secara ilegal sebanyak 70 persen pada tahun 2014-2015, menurut Profauna. Garda Satwa Indonesia mencatat terjadinya kasus kekerasan terhadap hewan pada tahun 2015 dan jumlah tersebut mengalami kenaikan tiap tahunnya (Susanto, Wellson., \& Veronica, Maria, 2015). Beberapa hal yang harus diperhatikan bahwa Pemilik hewan harus rutin memberikan makanan dan minuman, serta perawatan terhadap hewan tersebut, baik dalam perawatan tubuh ataupun vaksinasi dan pemeriksaan kesehatan supaya hewan yang dipelihara tidak mudah terkena virus atau terjangkit suatu penyakit. Oleh karena itu penting bagi pemelihara untuk mengetahui klinik hewan yang beroperasi di daerah tempat tinggal mereka untuk melakukan konsultasi dalam waktu tertentu. Karena permasalahan hubungan yang erat antara manusia dan hewan dimana mereka saling mempengaruhi satu dengan yang lain baik disisi positif seperti bekerjasamanya manusia dan hewan untuk suatu tujuan atau sisi buruk seperti penularan penyakit di antara mereka, maka dibutuhkan sebuah lembaga yang memadai untuk memastikan semua hal-hal positif dapat terwujud dan mengontrol hal-hal negatif sesegera mungkin (Wery, Indrawan., Ivan, Gunawan., 2014). Membuat Sistem 
Informasi berbasis website untuk membantu

klinik hewan Drh. I Made dalam mencatat rekam medis pasien yang dimana saat ini klinik tersebut masih menggunakan sistem manual (Emayanti, N. G. A. K., Werthi, K, T,. \& Satwika, I, 2019). Beberapa tempat yang sering kita jumpai yaitu pet shop, pet hotel, pet grooming dan pet clinic. Pet shop adalah tempat/toko yang menyediakan barang-barang untuk memenuhi kebutuhan hewan peliharaan/hewan kesayangan, dan yang lainnya ada pet hotel yaitu tempat untuk menitipkan hewan peliharaan, sedangkan pet clinic untuk pemeriksaan kesehatan hewan dan pet grooming untuk perawatan hewan. Dimana pemeriksaan kesehatan dan perawatan hewan itu sangat penting bagi hewan peliharaan dan bagi pemilik hewan tersebut (Wijayanti, 2015).

Namun pada saat ini, beberapa klinik hewan masih melakukan pengelolaan data secara manual ketika pemilik hewan dating ke klinik tersebut untuk setiap proses yang berjalan, seperti proses pendaftaran, pemeriksaan, dan transaksi. Tidak jarang ketika dating ke klinik, pemilik hewan harus menunggu karena banyaknya pasien yang harus ditangani. Petugas juga harus teliti dalam mencatat keluhan dari setiap pemilik hewan sebelum nantinya diberikan kepada dokter yang memeriksa. Masalah lain yang harus dihadapi ketika klinik tersebut merupakan klinik yang baru berkembang dan ditangani oleh satu dokter setiap harinya yang juga merangkap sebagai bagian administrasi pasien. Sehingga tidak jarang data-data yang terdapat pada klinik tersebut salah ataupun hilang. Pencatatan data yang mereka lakukan menjadi berantakan dan tidak sesuai dengan data yang seharusnya. Berdasarkan permasalahan yang muncul, diperlukan sebuah aplikasi pendaftaran dan transaksi pasien dalam modul pengelolaan data klinik hewan berbasis android yang mampu mengelola data setiap klinik hewan serta mampu mengikuti perkembangan dari klinik hewan tersebut. Aplikasi tersebut berisi fitur-fitur yang akan dibedakan dalam tiga kategori dan digunakan sesuai dengan pilihan admin. Setiap pemilik hewan ketika mendaftar kemudian akan mendapatkan konfirmasi melalui inbox yang terdapat pada aplikasi. Berdasarkan hasil survei yang dilakukan di beberapa klinik hewan di Bandung muncul beberapa masalah dari aspek pemilik hewan seperti pemilik hewan melakukan pendaftaran secara berulang sehingga itu akan menimbulkan duplikasi data pasien dan pemilik hewan pada klinik tersebut (Rizkita et al., 2018) . Maka dari itu dibutuhkan adanya sistem pendaftaran untuk mendapat nomor antrian yang sudah tervalidasi dengan data rekam medis pasien yang sudah ada sebelumnya. 


\section{Tinjauan Pustaka}

\subsection{PerancanganSistem}

(Mulyani, 2017) pengertian Perancangan sistem adalah penentuan proses dan data yang diperlukan oleh sistem baru. Tujuan dari perancangan sistem adalah untuk memenuhi kebutuhan pemakai sistem serta untuk memberikan gambaran yang jelas dan rancang bangun yang lengkap.

(Muharto, M., Hasan, S. and Ambarita, 2016) mendefinsikan peranacangan sistem dalam bukunya yang berjudul Metode Penelitian Sistem Informasi, perancangan sistem adalah suatu fase dimana diperlukan suatu keahlian perancangan untuk elemenelemen komputer yang akan menggunakan sistem yaitu pemilihan peralatan dan program computer untuk sistem yang baru.

Menurut (Jogiyanto, 2014) dalam jurnal menyatakan bahwa "Perancangan sistem adalah penggambaran, perencanaan, pembuatan sketsa dari beberapa elemen yang terpisah dalam satu kesatuan yang utuh dan berfungsi”.

Secara umum perancangan sistem bertujuan untuk memberikan gambaran jelas dari sistem yang dirancang dari beberapa elemen yang terpisah kedalam satu kesatuan yang utuh dan lengkap pada programmer komputer serta ahli teknik yang terlibat didalamnya.
Menurut (Mujilan, 2013), Tujuan yang hendak dicapai dari tahap perancangan sistem mempunyai maksud atau tujuan utama, yaitu sebagai berikut:

1. Untuk memenuhi kebutuhan pemakaian sistem (user)

2. Untuk memberikan gambaran yang jelas dan menghasilkan rancangan bangun yang lengkap kepada pemograman komputer dan ahli-ahli teknik lainnya yang terlibat dalam pengembangan atau pembuatan sistem

\subsection{SistemInformasi}

Menurut (Cegielski, 2015) Sistem informasi adalah proses mengumpulkan, memproses, menganalisis, dan menyebarkan informasi untuk tujuan tertentu. Sedangkan menurut (Brien, J. O., \& Markas, 2011)Sistem informasi adalah suatu kombinasi teratur apapun baik dari people, hardware, software, maupun database yang mengumpulkan, mengubah, dan menyebarkan informasi di dalam suatu bentuk organisasi.

\subsection{KlinikHewan}

Klinik hewan merupakan tempat untuk usaha dalam melakukan pelayanan pada jasa veteriar yang akan dijalankan dalam suatu manajemen yang dipimpin oleh seorang dokter hewan yang bertanggung jawab melakukan pengamatan untuk mendapatkan gangguan pada kesehatannya. 
Vaksinasi dan pelayanan kesehatan hewan 1 ainnya pada ternak besar (sapi/kerbau), ternak kecil (kambing/domba) maupun hewan kesayangan (anjing/ kucing /kelinci /burung) dan unggas serta penyuluhan kesehatan hewan, serta pelayanan gangguan reproduksi, inseminasi buatan dan penyuluhan kesehatan hewan. Dikarenakan banyak masyarakat yang memiliki hewan kesayangan seperti (anjing, kucing, kelincidll) sebagai hewan peliharaan yang akan bersifat komersial yang akan terus meningkat, sehingga perlu adanya kesehatan hewan yang dapat mencegah terjadinya penularan penyakit kepada manusia (zoonosis) yang disebabkan oleh virus rabies pada anjing/kucing.

\subsection{Android}

Menurut (Arifianto, 2011) android merupakan perangkat bergerak pada sistem operasi untuk telepon seluler yang berbasis linux .Menurut Hermawan (2011 : 1), Android merupakan OS (Operating System) Mobile yang tumbuh ditengah OS lainnya yang berkembang dewasa ini. OS lainnya seperti Windows Mobile, i-Phone OS, Symbian, dan masih banyak lagi. Akan tetapi, OS yang ada ini berjalan dengan memprioritaskan aplikasi inti yang dibangun sendiri tanpa melihat potensi yang cukup besar dari aplikasi pihak ke tiga. Oleh karena itu, adanya keterbatasan dari aplikasi pihak ketiga untuk mendapatkan data asliponsel, berkomunikasi antar proses serta keterbatasan distribusi aplikasi pihak ketiga untuk platform mereka. Android menurut Nazaruddin (2012 : 1) merupakan sistem operasi untuk telepon seluler yang berbasis Linux. Android menyediakan platform terbukabagi para pengembang untuk menciptakan aplikasi mereka sendiri untuk digunakan oleh bermacam peranti bergerak. Android umum digunakan di smartphone dan juga tablet PC. Fungsinya sama seperti sistem operasi Symbian di Nokia, iOS di Apple dan BlackBerry OS.

\subsection{Model}

\section{PengembanganPerangkatLunak}

"Model SDLC air terjun (waterfall) sering juda disebut model sekuensial linier (sequential linier) atau alur hidup klasik (classic lifcycle)" (Soekamto \& Shalahuddin 2016:28)

Berikut adalah gambar model air terjun:

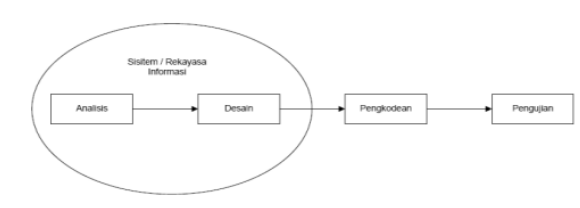

Sumber :(Sukamto, 2016)

Gambar 1.

Ilustrusi Model Waterfall

Penjelasandari model tersebut, sebagaiberikut :

1. AnalisaKebutuhanPerangkatLunak 
Proses pengumpulan kebutuhan dlakukan secara intensif untuk mespesifikasikan kebutuhan perangkat lunak agar dapat dipahami perangkat lunak seperti apa yang dibutuhkan oleh user. Spesifikasi perangkat lunak pada tahap ini perlu untuk didokumentasikan.

\section{Desain}

Desain perangkat lunak adalah proses multi langkah yang fokus pada desain pembuatan program perangkat lunak termasuk struktur data, arsitektur perangkat lunak, representasi antarmuka, dan prosedur pengkodean. Tahap ini mentranslasi kebutuhan perangkat lunak dari tahap analisis kebutuhan ke representasi desain agar dapat diimplementasikan menjadi program pada tahap selanjutnya. Desain peangkat lunak yang dihasilkan pada tahap ini juga perlu didokumentasikan.

\section{Pembuatan Kode Program}

Desain harus ditranslasikan kedalam program perangkat lunak. Hasil dari tahap ini adalah program komputer sesuai dengan desain yang telah dibuat pada tahap desain.

\section{Pengujian}

Pengujian fokus pada perangkat lunak secara dari segi lojik dan fungsional dan memastikan bahwa semua bagian sudah diuji. Halini dilakukan untuk meminimalisir kesalahan (error), dan memastikan keluaran yang dihasilkan sesuai dengan yang diinginkan.

\subsection{TeoriPendukung}

\section{Unified Modeling Language}

Menurut (Adi Nugroho, 2010) pengertian UML atau UnifiedModeling Language ialah bahasa pemodelan khusus untuk sistem atau perangkat lunak dengan paradigma "beriorientasi objek". Pemodelan atau modeling sebenarnya digunakan khusus untuk menyederhanakan berbagai kendala yang kompleks sehingga nantinya mudah untuk dipelajari dan dipahami. Menurut (Prabowo Pudjo Widodo, 2011) bahwa berbagai literature menjelaskan bahwa UML memiliki 9 jenis diagram, tetapi ada juga yang menyebutkan hanya ada 8 karena beberapa diagram digabung seperti diagram urutan, diagram komunikasi dan juga diagaram pewaktuan yang digabung menjadi diagram interaksi.

\section{Hasil dan Pembahasan}

\subsection{Analisa KebutuhanSistem}

Pada

analisakebutuhansisteminiterdiridari :

1. Analisa KebutuhanSistem
a. Login sebagaipasien
b. Login Sebagaipetugas
c. Login sebagaidokter

2. Analisa Kebutuhansebagaipasien

Agar dapat menggunakan aplikasi, pasien diharuskan untuk melakukan log in. Jika belum terdaftar maka pasien diharuskan untuk mendaftar terlebih dahulu 
agar bisa log in menggunakan username dan password yang diberikan.Setelah berhasil log in,maka akan muncul form utama untuk pasien pada aplikasi klinik. Form ini memiliki beberapa pilihan menu, yaitu :

a. Pendaftaran

Menu Pendaftaran digunakan agar pasien lebih mudah untuk melakukan pendaftaran online.

\section{b. Data Pasien}

Menu Data Pasien berisi No.rekam medis, nama, alamat, nama pemilik.

\section{c. Pemesanan}

Pemilik hewan bisa memilih jadwal dokter yang sudah ada pada klinik hewan yang dipilih, menulis keluhan yang dialami hewan peliharaan.

d. Inbox

Pada menu inbox berisi bukti pendaftaran.

3. Analisa Kebutuhan user sebagai petugas

Sama seperti pasien, petugas diharuskan untuk melakukan log in dengan username dan password petugas. Setelah berhasil log in, maka akan muncul form utama untuk petugas pada aplikasi klinik. Form ini memiliki pilihan menu yaitu

a. Konfirmasi berobat pasien

Petugas menerima pendaftaran pasien dengan mencocokkan jadwal dokter lalu menyetujui pendaftaran/memberikan konfirmasi kepada pasien dan membuat laporan pendaftaran. b. Data Transaksi

Menu transaksi berisi konfirmasi pembayaran (sudah terbayar atau belum).

c. Pasien Terdaftar

Menu Pasien Terdaftar memiliki sub menu, yaitu sub menu Konfirmasi Berobat Pasien dan Pasien Terdaftar.

4. Analisa Kebutuhan user sebagaidokter

Dokter diharuskan untuk melakukan log in dengan username dan password dokter. Setelah berhasil log in, maka akan muncul form utama untuk dokter pada aplikasi klinik. Form ini memiliki beberapa pilihan menu, yaitu :

a. Pemeriksaan Pasien

Menu Pemeriksaan Pasienberisi Daftar antrian pasien dan data pasien yang akan diperiksa.

b. CatatanMedis

Pengisian Medis dan Pemberian Resep berisi Data Pasien (No.rekam medis, nama, umur), Hasil Pemeriksaan dan Resep.

c. Data RekamMedis

Data Rekam Medis berisi semua data rekam medis pasien.

5. Class Diagram 


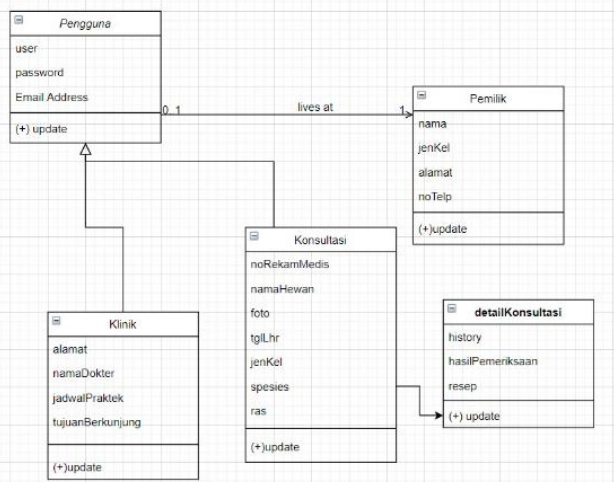

Gambar 1.Class Diagram KlinikHewan

6. Implementasi MockUp

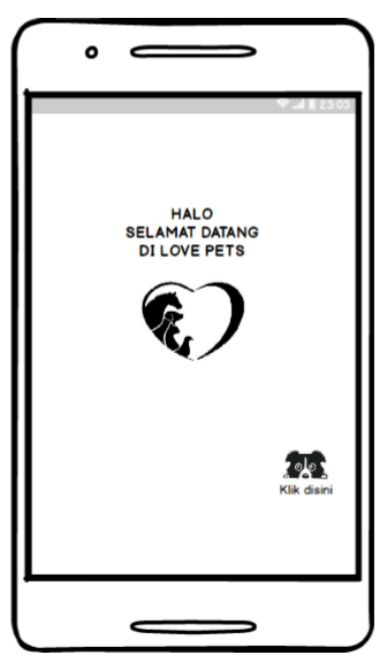

Gambar 2. Halaman Utama

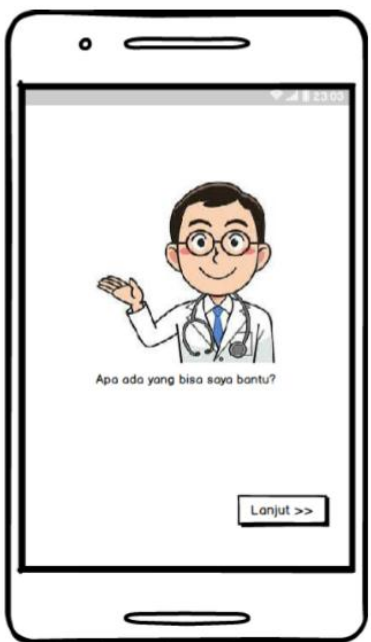

Gambar 3. Halaman Mulai

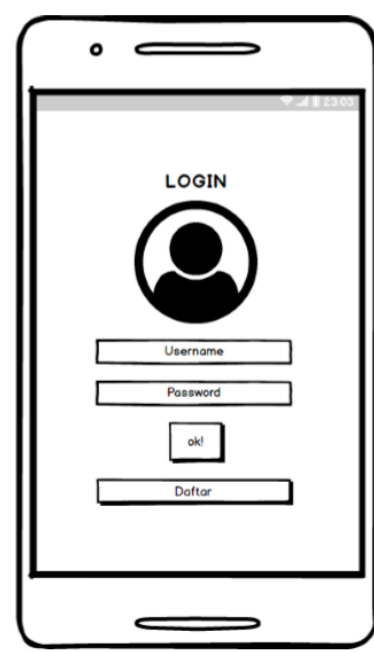

Gambar 4. Halaman Login

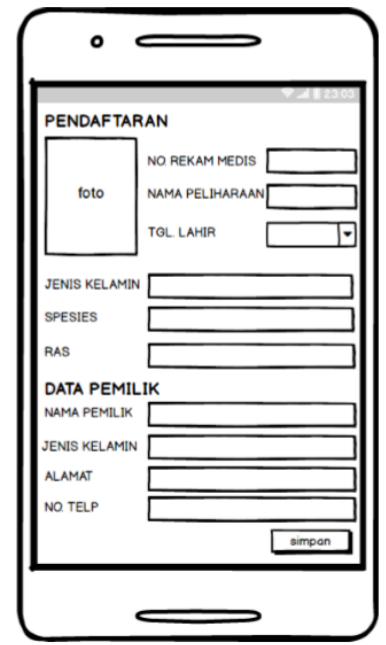

Gambar 5. Halaman Pendaftaran

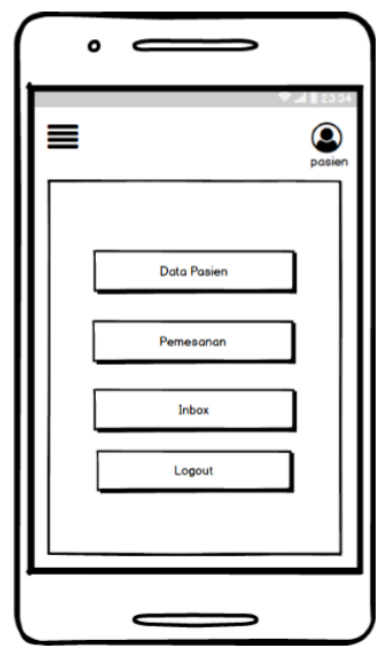

Gambar 6. Halaman Pasien 


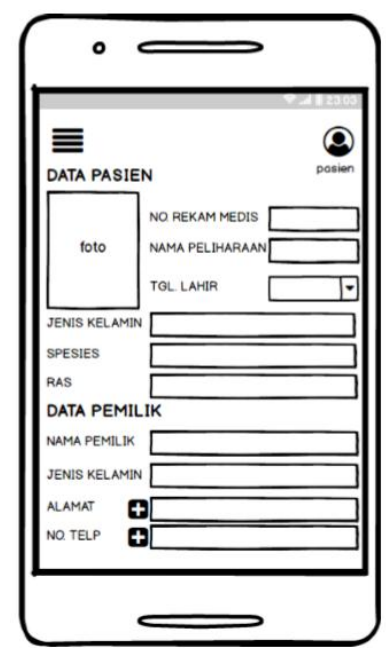

Gambar 7. Halaman Data pasien

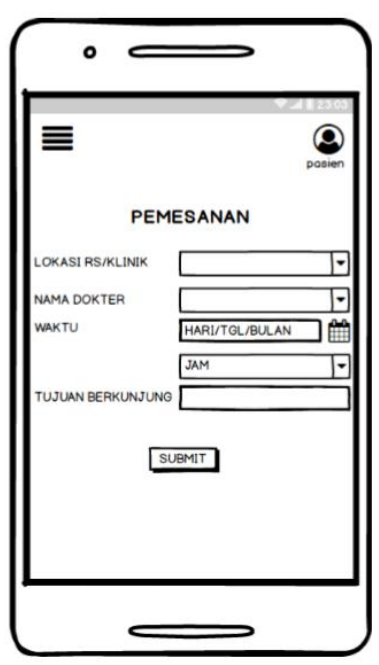

Gambar 8. Halaman Pemesanan

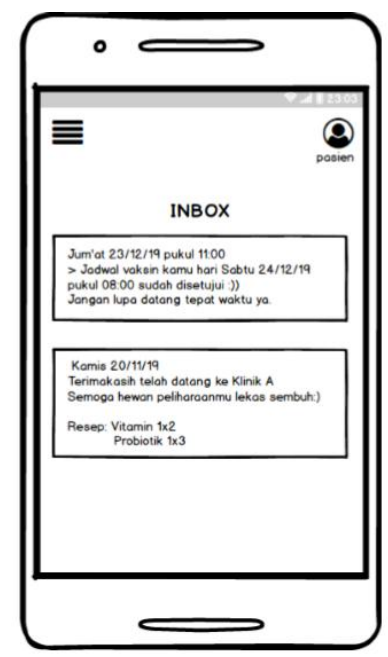

Gambar 9. Halaman Inbox

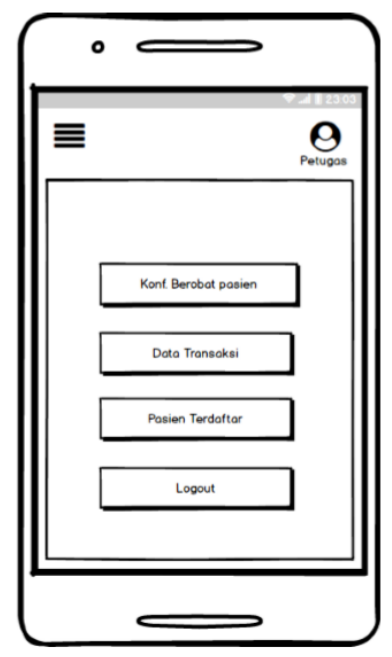

Gambar 10. Halaman Petugas

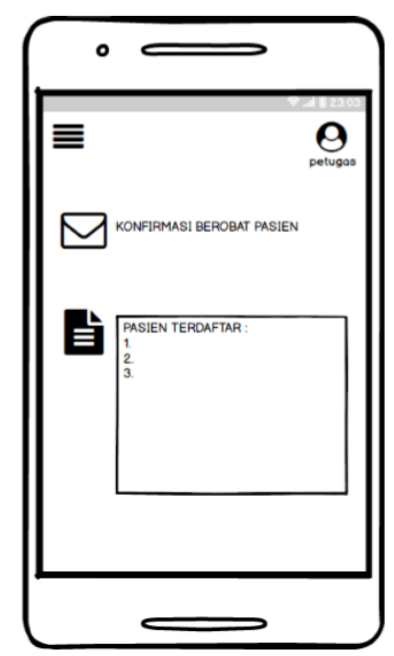

Gambar 11. Halaman PasienTerdaftar

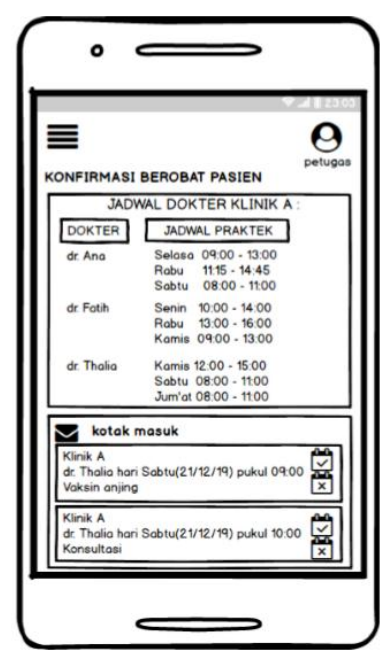

Gambar 12. Halaman

KonfirmasiBerobatPasien 


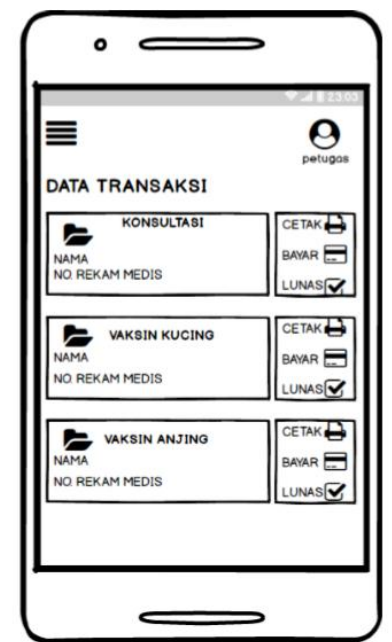

Gambar 13. Halaman Data Transaksi

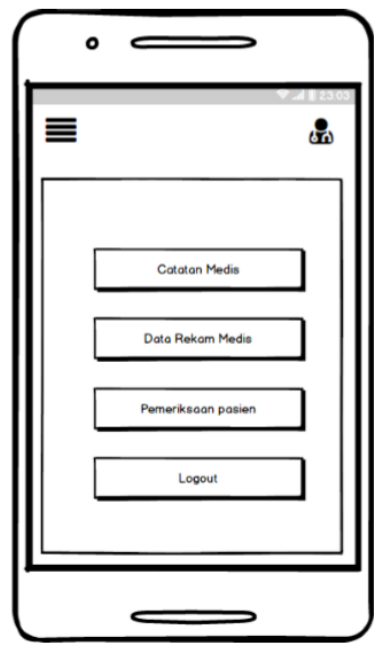

Gambar 14. Halaman Dokter

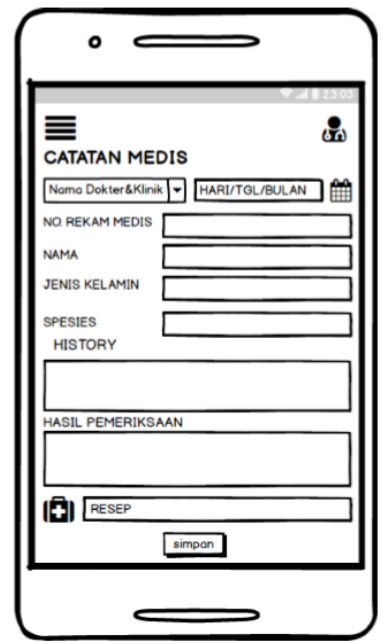

Gambar 15. Halaman CatatanMedis

\subsection{Kesimpulan}

Perancangan Sistem Informasi dirancang sesuai kebutuhan dari salah satu klinik hewan, oleh karena itu dapat dijadikan sebagai dasar untuk membuat aplikasi mobile. Pengguna aplikasi ini akan dipermudah kinerjanya dapat fleksibel menggunakan smartphone. Dari sisi pasien akan sangat terbantu sekali dengan adanya aplikasi ini.

\subsection{Saran}

Tentunya Perancangan Sistem Informasi Klinik Hewan ini belum sempurna dan masih ada kekurangan karena perlu adanya implementasi lebih lanjut dari program yang telah dibangun sistem aplikasi Android dengan berbasis mobile supaya dapat langsung digunakan oleh klinik hewan yang membutuhkan. Adapun yang perlu dikembangkan yaitu pada fitur keamanan perlu ditingkatkan agar sistem menjadi lebih baik. Serta perlu ditambahkan notif apabila ada pasien yang mendaftar untuk berobat.

\subsection{Daftar Pustaka}

Adi Nugroho. (2010). Rekayasa Perangkat Lunak Berbasis Objek dengan Metode USDP.

Arifianto, T. (2011). Membuat Interface Aplikasi Android Lebih Keren dengan LWUIT. Andi Publisher.

Brien, J. O., \& Markas, G. (2011). Management Information System. 10.

Cegielski, R. P. (2015). Introduction to Information System. John Wiley and 


\section{Sons.}

Emayanti, N. G. A. K., Werthi, K, T,. \& Satwika, I, P. (2019). Model Sistem Informasi Klinik Hewan Berbasis Website (Studi Kasus Klinik Drh. I Made Jiestara-Denpasar). Jutisi : Jurnal Ilmiah Teknik Informatika Dan Sitem Informasi, 8 (2), 35-44.

Jogiyanto, H. . (2014). Analisis Desain dan Desain Sistem Informasi. Elex Media Komputerindo.

Muharto, M., Hasan, S. and Ambarita, A. (2016). Penggunaan Model E-learning dalam Meningkatkan Hasil Belajar Mahasiswa pada Materi Microprocessor. Indonesian Journal on Information Systems, 2, 1.

Mujilan, A. (2013). Analisis dan Perancangan Sistem. Univ. Widya Mandala Madiun.

Mulyani, S. (2017). Metode Analisis dan Perancangan Sistem. Abdi Sistematika.

Prabowo Pudjo Widodo, dan H. (2011). Menggunakan UML, Unified Modeling Language”. Informatika Bandung.

Rebecca, Y. (2012). Pengaruh Corporate Governance Index, Kepemilikan Keluarga, dan Kepemilikan Institusional terhadap Biaya Ekuitas dan Biaya Utang: Studi Empiris pada Perusahaan Manufaktur yang Terdaftar di BEI. Skripsi Fakultas Ekonomi Dan Bisnis Universitas Indonesia.

Rizkita, N., Rosely, E., \& Nugroho, H. (2018). Aplikasi Pendaftaran dan Transaksi Pasien Klinik Hewan di Bandung Berbasis Web. EProceedings of Applied Science, 4(3), 1512-1520.

Sukamto, A. R. dan S. . (2016). Rekayasa Perangkat Lunak Terstruktur dan
Berorientasi Objek. Informatika Bandung.

Susanto, Wellson., \& Veronica, Maria, G. (2015). Pusat Edukasi Tentang Hewan Peliharaan Di Kelapa Gading. Jurnal Kajian Teknologi, 11 (1) Mar.

Wery, Indrawan., Ivan, Gunawan., M. R. A. (2014). Rumah Sakit Hewan Di Kota Pontianak. Jurnal Online Mahasiswa Arsitektur Universitas Tanjung Pura, 2 (1), 1-18.

Wijayanti, R. M. (2015). Solo Pet Centre Sebagai Sarana Edukasi dan Rekreasi Keluarga. 